DOI: $10.19195 / 2084-5065.50 .5$

\title{
Konsensualne zakończenie postępowania przygotowawczego w trybie art. 355 k.p.k.
}

\author{
PiOTR KowAlCZYK \\ ORCID: 0000-0002-4140-6221 \\ Prokuratura Krajowa w Warszawie
}

W polskiej procedurze karnej już ponad dwadzieścia lat temu ustawodawca przewidział możliwość konsensualnego zakończenia postępowania karnego. Pierwsze tego typu uregulowanie prawne zawarto w Kodeksie postępowania karnego z 1997 roku¹. W ciągu lat wspomniana instytucja procesowa ewaluowała, ustawodawca przyjmował różne rozwiązania dotyczące zarówno formy, jak i treści zawarcia ugody. Jednakże okres obowiązywania przepisów w tym zakresie oraz ich ewolucja, co wykażę poniżej, wskazuje w dobitny sposób na to, że instytucja ugody procesowej została $\mathrm{w}$ pełni zaadaptowana do polskiego systemu prawnego i stanowi jego nieodzowny element.

Obecnie obowiązujące przepisy dopuszczają zawarcie ugody procesowej zarówno na etapie postępowania przygotowawczego, jak i w trakcie postępowania sądowego. Niezależnie od etapu sprawy, w której dochodzi do dobrowolnego poddania się karze przez podejrzanego lub oskarżonego, można wyróżnić kilka elementów wspólnych. Przede wszystkim ostateczne rozstrzygnięcie zawartej ugody, poprzez jej prawomocne usankcjono-

1 Ustawa z dnia 6 czerwca 1997 r., Kodeks postępowania karnego (Dz.U. z 1997 r. Nr 89, poz. 555). 
wanie, należy do sądu. Ponadto podkreślono ochronę praw pokrzywdzonego w postępowaniu karnym, co organ procesowy musi uwzględniać, dążąc do zawarcia ugody z podejrzanym lub oskarżonym, albowiem sprzeciw pokrzywdzonego niweczy kwestie dotyczące zawartej ugody.

Przepisami, które bezpośrednio odnoszą się do instytucji ugody procesowej, są regulacje stypizowane w art. 335 k.p.k., 338a k.p.k. i art. 387 k.p.k. Przepisem pośrednio odnoszącym się do kwestii ugody w procesie karnym jest unormowanie zawarte w art. 343 k.p.k., które dotyczy sposobu procedowania wniosku złożonego w trybie art. 335 k.p.k. przed sądem $^{2}$.

W świetle obowiązującego prawa skazanie bez rozprawy, chociaż w całości uregulowane w Kodeksie postępowania karnego, stanowi swoisty konglomerat przepisów karnych o charakterze materialnoprocesowym, co jest implikowane głównie przez treść art. 343 k.p.k., ponieważ przepis ten oprócz kwestii proceduralnych zawiera normy dające podstawę do pośredniego zastosowania instytucji prawa karnego materialnego ${ }^{3}$.

Niniejsze opracowanie skupione jest na zawieraniu ugody procesowej w trybie art. 335 k.p.k. oraz jej proceduralnych konsekwencjach. Opierając się na teorii oraz praktyce wynikającej głównie z orzecznictwa, postaram się przedstawić kwestie związane z funkcjonowaniem konsensualnego trybu procedowania w polskiej procedurze karnej na podstawie przywołanego przepisu.

W obecnie obowiązującym Kodeksie postępowania karnego ugoda przewidziana w art. 335 k.p.k. może zostać zmaterializowana w formie samoistnego wniosku kierowanego do właściwego rozpoznania sprawy sądu lub też w formie wniosku dołączonego do aktu oskarżenia.

Wniosek w trybie art. 335 § 1 k.p.k. może zostać skierowany w każdej sprawie, której przedmiotem jest przestępstwo będące występkiem. Wystąpienie $\mathrm{z}$ takim pismem procesowym wymaga zaistnienia konkretnych przesłanek procesowych. Stosownie do brzmienia powołanego przepisu podejrzany musi przyznawać się do winy i złożyć wyjaśnienia, które nie będą sprzeczne z poczynionymi ustaleniami zarówno co do okoliczności

\section{Ibidem.}

3 M. Jankowski, A. Ważny, Instytucja dobrowolnego poddania się karze (art. 387 k.p.k.) i skazania bez rozprawy (art. 335 k.p.k.) w świetle praktyki. Rezultaty badań ogólnopolskich, „Prawo w Działaniu” 2008, nr 3, s. 118-151. 
popełnienia przestępstwa, jak i okoliczności dotyczących winy, a więc strony podmiotowej przestępstwa. Istotne $\mathrm{z}$ punktu praktycznego jest podkreślenie, iż zgodnie z utrwalonym orzecznictwem ustalenie, że podejrzany leczył się psychiatrycznie, lub też stwierdzenie innych okoliczności implikujących możliwość braku poczytalności lub jej ograniczenie tempore criminis po stronie podmiotowej przestępstwa musi spowodować powołanie dwóch biegłych lekarzy psychiatrów w celu ustalenia, czy w sprawie nie zachodzą okoliczności wskazane w art. 31 § 1 i 2 k.k., albowiem bez tej opinii niemożliwe będzie przyjęcie przez sąd, że wina oskarżonego nie budzi wątpliwości. Teza ta znalazła odzwierciedlenie w wyroku Sądu Najwyższego z dnia 25 maja 2017 roku, sygn. V KK 129/17:

Jeżeli sąd dysponuje sygnałem wskazującym na istnienie wątpliwości co do stanu zdrowia psychicznego oskarżonego, bowiem przy przesłuchaniu w postępowaniu przygotowawczym oskarżony oświadczył, że leczy się psychiatrycznie na depresję, to przyjęcie przez sąd, że wina oskarżonego nie budzi wątpliwości (art. 335 § 1 k.p.k.), jest bezpodstawne ${ }^{4}$.

Ponadto organ procesowy, planując wystąpienie z takim wnioskiem, jak i wydając na jego podstawie orzeczenie, musi wziąć pod uwagę kwestię dotyczących osiągnięcia celów postępowania, a więc pamiętać o względach dotyczące prewencji indywidualnej oraz ogólnej. Jeżeli wyjaśnienia podejrzanego budzą wątpliwości w zakresie dotyczącym ich wiarygodności, organ procesowy powinien przeprowadzić czynności w niezbędnym zakresie w celu dokonania oceny wiarygodności wyjaśnień. Czynności te będą miały na celu przede wszystkim dokonanie oceny postawy podejrzanego, a także ustalenie sprawstwa w kontekście zrzucanego czynu. Należy podkreślić, iż same wyjaśnienia podejrzanego, w których przyznaje się do winy, nie mogą stanowić wystarczającej przesłanki sformułowania wniosku w trybie art. $335 \S 1$ k.p.k., jeżeli organ procesowy powziąłby wątpliwości co do okoliczności zdarzenia, a więc do sprawstwa podejrzanego ${ }^{5}$. $\mathrm{O}$ ile wskazane działania procesowe mają charakter fakultatywny, to $\mathrm{w}$ świetle brzmienia przywołanego prze-

${ }^{4}$ Wyrok Sądu Najwyższego z dnia 25 maja 2017 r. sygn. V KK 129/17, LEX nr 2298316.

5 Wyrok Sądu Apelacyjnego w Katowicach z dnia 18 stycznia 2018 r., sygn. V ACa 874/16, [w:] LEX nr 2442698. 
pisu nie ulega wątpliwości, iż ustawodawca zobligował organy procesowe do wykonania czynności mających na celu zabezpieczenie materiału dowodowego, które zostały wskazane w art. 308 k.p.k.

Wymaga podkreślenia, iż formułując poczyniony wniosek, prokurator musi mieć na uwadze prawnie chroniony interes pokrzywdzonego, a więc ustalona kara powinna zawierać elementy dotyczące ochrony praw osoby pokrzywdzonej przestępstwem zarówno w sferze materialnej: naprawienie szkody, nawiązka itp.: jak i niematerialnej: przeproszenie pokrzywdzonego, zakaz kontaktu z pokrzywdzonym itp. Artykuł 343 $\S 2$ k.p.k. wprost stanowi, iż uwzględnienie wniosku złożonego w trybie art. 335 k.p.k. przez sąd może nastąpić, jeżeli nie sprzeciwi się temu pokrzywdzony prawidłowo powiadomiony o terminie posiedzenia. $Z$ tych względów wskazane jest, aby pokrzywdzonego już na etapie postępowania przygotowawczego zaangażować w konstruowanie ugody, albowiem jego stanowisko ma fundamentalne znaczenie przy procedowaniu przez sąd. Z tego powodu nie jestem w stanie w pełni zaakceptować tezy Radosława Kopera, iż konkretyzacja wniosku o skazanie bez rozprawy powinna nastąpić dopiero w trakcie posiedzenia przed sądem ${ }^{6}$. Natomiast na aprobatę zasługuje pogląd wyrażony przez Sławomira Steinborna, który stanowi poparcie wskazanej tezy dotyczącej uzgadniania treści wniosku konsensualnego w trakcie postępowania przygotowawczego:

W doktrynie powszechnie przyjmowany jest pogląd, iż wniosek o skazanie w trybie konsensualnym musi zawierać konkretną treść (zob. rozdział drugi, pkt 3.3.5.). Jest to o tyle istotne, iż w przypadku uwzględnienia wniosku sąd jest związany jego treścią. W konsekwencji istotnego znaczenia nabiera zbadanie, czy wymóg ten został spełniony oraz czy propozycje wniosku posiadają odpowiedni stopień konkretyzacji ${ }^{7}$.

Istotny z punktu widzenia zachowania gwarancji procesowych jest sposób uzyskania od podejrzanego zgody na skazanie bez przeprowadzania rozprawy, a także forma jego utrwalenia. Druga kwestia wydaje się jednoznaczna. Przedmiotowy wniosek powinien być złożony w formie pisemnej, a jego treść i autorstwo nie powinny budzić wątpliwości. Propozycja konsensualnego zakończenia postępowania przygotowawczego

${ }^{6}$ R. Koper, Dwa tryby skazania bez rozprawy w procesie karnym, „Państwo i Prawo" 2016, nr 10, s. 27-46.

7 S. Steinborn, Porozumienie w polskim procesie karnym. Skazanie bez rozprawy i dobrowolne poddanie się odpowiedzialności karnej, Kraków 2005, s. 46. 
powinna pochodzić od organu procesowego, a zgoda na jej uwzględnienie od podejrzanego. Jeżeli podejrzany ma obrońcę, wówczas oświadczenie obrońcy w powyższym zakresie nie może zastąpić oświadczenia podejrzanego, jednakże stanowisko podejrzanego, w przypadku posiadania przez niego obrońcy, musi być mu znane i obrońca, choćby w sposób domniemany, powinien zająć w tej kwestii stanowisko. Wyrażenie zgody przez podejrzanego na zaproponowane mu warunki ugody procesowej powinno nastąpić do protokołu jego przesłuchania lub do protokołu końcowego zaznajomienia $\mathrm{z}$ materiałami postępowania albo powinno nastąpić w odrębnym piśmie ${ }^{8}$. Moim zdaniem przez odrębne pismo należy rozumieć złożone pisemnie oświadczenie podejrzanego, względnie jego obrońcy, ale w obu tych wypadkach należy wezwać podejrzanego do złożenia do protokołu oświadczenia dotyczącego treści przedłożonego pisma, które może stanowić załącznik do protokołu.

Z praktycznego punktu widzenia ważne jest sformułowanie wniosku w sytuacji ostatecznego opracowania zarzutów dla podejrzanego. Zgodnie $\mathrm{z}$ brzmieniem $\S 233$ ust. 1 Regulaminu wewnętrznego urzędowania powszechnych jednostek organizacyjnych prokuratury ${ }^{9}$ każda zmiana lub uzupełnienie postanowienia o przedstawieniu zarzutów wymaga dokonania z podejrzanym ponownych ustaleń dotyczących stosowania instytucji art. $335 \S 1$ lub $\S 2$ k.p.k.

Ponadto przy zawieraniu ugody procesowej podejrzany powinien zostać pouczony o treści art. 447 § 5 k.p.k., co powinien potwierdzić własnoręcznym podpisem ${ }^{10}$. Przepis ten dotyczy ograniczenia zakresu zaskarżania wyroku wydanego $\mathrm{w}$ wyniku porozumienia zawartego na podstawie art. 335 k.p.k.

W przypadku spełnienia wszystkich wspomnianych przesłanek prokurator kieruje do sądu wniosek, zamiast aktu oskarżenia, o wydanie wyroku skazującego. Wniosek musi zawierać uzgodnione z podejrzanym orzeczenie co do kary i środków, których wymierzenie ustawodawca przewidział w związku z popełnieniem przez podejrzanego przypisanego mu we wnio-

${ }^{8}$ Rozporządzenie Ministra Sprawiedliwości z dnia 7 kwietnia 2016 r. Regulamin wewnętrznego urzędowania powszechnych jednostek organizacyjnych prokuratury (tekst jedn. Dz.U. z 2017 r. poz 1206).

${ }^{9}$ Ibidem.

10 Ibidem. 
sku przestępstwa. Istotne jest, aby konstruując wniosek oraz propozycje wymiaru kary, organ procesowy nie tracił z pola widzenia reguł ustalania wymiaru kar oraz uwzględniania ich ustawowych celów ${ }^{11}$.

Ważne jest też to, iż oprócz kar i środków organ procesowy może także uzgodnić z podejrzanym rozstrzygnięcie dotyczące kosztów procesu. Wymaga podkreślenia, iż nie jest to obligatoryjny element omawianego wniosku, jednakże z przyczyn pragmatycznych, szczególnie dla podejrzanego, należy uznać, iż powyższa kwestia powinna być odzwierciedlona w zawartej ugodzie. Nie można zapominać, iż ustawodawca przewidział, że wyrażenie zgody lub niewyrażenie sprzeciwu na całkowite lub częściowe zwolnienie oskarżonego z kosztów sądowych może nastąpić jedynie w przypadku zaistnienia przesłanek stypizowanych w art. 624 $\S 1$ k.p.k. Ponadto zgodnie z brzmieniem art. 335 § la k.p.k. wniosek samoistny powinien spełniać wymogi formalne dotyczące aktu oskarżenia (art. 332 k.p.k.), a jego procedowanie odbywa się stosownie do brzmienia przepisów wskazanych w rozdziale 40 Kodeksu postępowania karnego, z wyjątkiem przepisu dotyczącego zwrotu sprawy do postępowania przygotowawczego w celu uzupełnienia istotnych braków tego postępowania, ponieważ w przypadku zaistnienia przesłanek uniemożliwiających procedowanie wniosku stosuje się art. 335 § 4 k.p.k. Uzasadnienie wniosku złożonego w trybie art. 335 k.p.k. stosownie do brzmienia $\S 2$ tego przepisu powinno się ograniczyć do wskazania dowodów przemawiających za tym, że spełniono przesłanki z art. 335 § 1 k.p.k. w zakresie dotyczącym okoliczności niebudzących wątpliwości odnośnie do popełnienia przestępstwa i winy oskarżonego oraz dotyczące osiągnięcia celów postępowania bez przeprowadzania rozprawy. Mając na uwadze ratio legis przepisu art. 335 § 1 k.p.k., które dąży między innymi do maksymalnego uproszczenia i przyspieszenia procedur podjętych w trybie konsensualnym, należałoby rozważyć postulat de lege ferenda, aby wniosek złożony w trybie art. $335 \S 1$ k.p.k. jeszcze bardziej odformalizować i zrezygnować z uzasadnienia, przynajmniej w zakresie, w jakim dotyczy ono okoliczności popełnienia przestępstwa, a więc dotyczących dowodów, które wskazują na sprawstwo oskarżonego, jedynie poprzesta-

11 Wyrok z dnia 28 czerwca 2017 r. Sądu Apelacyjnego w Warszawie, sygn. II Aka 133/17, LEX nr 2337045. 
jąc na uzasadnieniu dotyczącym uzgodnionego wymiaru kary. Wymaga podkreślenia, iż ustawodawca przewidział możliwość zrezygnowania ze sporządzenia uzasadnienia aktu oskarżenia złożonego w trybie wskazanym w art. $332 \S 3$ k.p.k. Konstrukcja ta pozostaje aktualna nawet przy przełamaniu zasady bezpośredniości, choćby poprzez wydanie wyroku nakazowego, co ma miejsce także w trybie konsensualnym.

$\mathrm{Z}$ wnioskiem złożonym $\mathrm{w}$ trybie art. $335 \S 1$ k.p.k. należy przekazać do sądu całość zgromadzonego w sprawie materiału dowodowego, który odnosi się zarówno do przestępstwa zarzucanego oskarżonemu, jak i do okoliczności mających znaczenie przy dokonaniu oceny strony podmiotowej przestępstwa, zwłaszcza w kontekście proponowanej kary za zarzucane przestępstwo. Przekazaniu podlegają przede wszystkim postanowienia i zarządzenia dotyczące osób oskarżonych, wydane $\mathrm{w}$ toku postępowania, protokoły z czynności wymagane przez ustawę, załączniki do tych protokołów, opinie i dokumenty urzędowe i prywatne uzyskane lub złożone do akt sprawy. W świetle orzecznictwa nie ulega wątpliwości, iż sąd procedujący powyższy wniosek nie może prowadzić postępowania dowodowego, a jedynie bazować na materiale procesowym przekazanym przez prokuratora. $Z$ tego względu bardzo ważna jest jego kompletność i adekwatność dotycząca związku z czynem zarzuconym oskarżonemu. Stanowisko to znalazło odzwierciedlenie w orzecznictwie. Sąd Najwyższy w wyroku z dnia 30 marca 2017 roku (sygn. III KK 404/1), stwierdził:

Skoro w razie uwzględnienia wniosku o skazanie bez rozprawy następuje rezygnacja $\mathrm{z}$ bezpośredniego postępowania dowodowego, to zgromadzony w postępowaniu przygotowawczym materiał dowodowy musi pozwalać na pełną i jednoznaczną ocenę zaistniałego zdarzenia przestępnego oraz jego sprawcy, tak aby brak było jakichkolwiek wątpliwości co do okoliczności popełnienia przestępstwa oraz winy sprawcy ${ }^{12}$.

Pewne wątpliwości budzi kwestia końcowego zapoznania się przez podejrzanego i jego obrońcę $\mathrm{z}$ aktami sprawy przed skierowaniem wniosku w trybie art. $335 \S 1$ k.p.k. oraz wydanie postanowienia o zamknięciu śledztwa. Wątpliwości wynikają z tego, że wniosek skierowany $\mathrm{w}$ powyższym trybie na pewno nie jest aktem oskarżenia w rozumieniu

12 Wyrok Sądu Najwyższego z dnia 30 marca 2017 r., sygn. III KK 404/16, [w:] LEX nr 2261730. 
art. 332 k.p.k. Jednakże poprzez swój charakter procesowy oraz brzmienie przepisu art. 335 § la k.p.k. nie powinno budzić wątpliwości, iż przedmiotowy wniosek stanowi quasi-akt oskarżenia szczególnie w zakresie skutków procesowych, które wywołuje w przypadku jego uwzględnienia przez sąd. Z tego względu w pełni przychylam się do tezy, że

Czynności końcowego zapoznania z materiałami oraz wydania postanowienia o zamknięciu śledztwa można zaniechać również w przypadku, gdy prokurator zamierza wystąpić do sądu na podstawie art. $335 \S 1 \mathrm{z}$ wnioskiem o wydanie na posiedzeniu wyroku skazującego i orzeczenie uzgodnionych z oskarżonym kar i innych środków. W takiej sytuacji stronom $\mathrm{i}$ ich przedstawicielom zgodnie $\mathrm{z}$ art. $335 \S 3$ zdanie czwarte przysługuje prawo do przejrzenia akt sprawy, o czym należy ich pouczyćc ${ }^{13}$.

W przypadku dołączenia wniosku o dobrowolne poddanie się karze w trybie art. $335 \S 2$ k.p.k. do aktu oskarżenia należy mieć na uwadze odmienność przesłanek skorzystania $\mathrm{z}$ tej instytucji procesowej w stosunku do wniosku kierowanego w trybie art. $335 \S 1$ k.p.k., a więc wniosku samodzielnego. Zgodnie z brzmieniem art. 335 § 2 k.p.k. dołączenie wniosku konsensualnego do aktu oskarżenia może nastąpić, jeżeli okoliczności popełnienia przestępstwa i wina oskarżonego nie budzą wątpliwości. W tym przypadku oskarżony nie musi przyznawać się do winy oraz składać wyjaśnień, co jest niezbędną przesłanką skierowania wniosku samoistnego. Ponadto oświadczenia dowodowe nie mogą pozostawać w sprzeczności z dokonanymi ustaleniami. Termin „oświadczenia dowodowe", moim zdaniem, należy rozmieć szeroko, a więc są to nie tylko wyjaśnienia podejrzanego i wnioski dowodowe złożone przez niego lub jego obrońcę, lecz także wszelkie pisma procesowe, w których podejrzany odnosi się do przeprowadzonych dowodów, kwestionując swoje sprawstwo w zakresie popełnienia zarzucanych mu przestępstw ${ }^{14}$. Należy przyjąć, że w sytuacji procesowego zweryfikowania wniosków dowodowych i ustalenia, iż są one bezprzedmiotowe w kontekście kwestionowania sprawstwa podejrzanego, nie będzie występowała negatywna przesłanka w zakresie dołączenia do aktu oskarżenia wniosku w trybie art. 335 § 2 k.p.k., ponieważ sprzeczność oświadczeń dowodowych powinna

13 Kodeks postępowania karnego. Komentarz do wybranych przepisów, red. S. Steinborn, LEX/el. 2016.

${ }^{14}$ R. Segierski, Akta oskarżenia z wnioskiem o skazanie bez rozprawy. Komentarz Praktyczny, LEX/el. 2016. 
wynikać nie tylko z ich treści, lecz także z wyników ich procesowej weryfikacji. Kolejną a zarazem ostatnią przesłanką zastosowania instytucji z art. $335 \S 2$ k.p.k. jest postawa oskarżonego, z której musi wynikać, iż cele postępowania karnego muszą zostać osiągnięte. Kryterium to odnosi się do strony podmiotowej przestępstwa i oznacza, iż organ procesowy, zawierając porozumienie z podejrzanym, a sąd procedując na tej podstawie, muszą uwzględniać wytyczne z art. 2 § 1 k.p.k. Cele postępowania wskazane w przywołanym przepisie w sposób bezpośredni lub pośredni odnoszą się do konsensualnego zakończenia konkretnej sprawy karnej. Jednakże mając na uwadze instytucje ugody procesowej, wydaje się, iż należy przede wszystkim uwzględnić cele postępowania dotyczące strony podmiotowej postępowania oraz pokrzywdzonego, a także cele związane z funkcją profilaktyczną prawa karnego. Przy formułowaniu warunków ugody organ procesowy na pewno musi wziąć pod uwagę interes pokrzywdzonego, który ostatecznie jest zobligowany do zajęcia stanowiska w kwestii akceptacji warunków konsensualnego zakończenia sprawy. Przesłanki zastosowania art. 335 § 1 i 2 k.p.k. odnoszące się do strony podmiotowej przestępstwa, a także mające na celu uniknięcie pociągnięcia do odpowiedzialności karnej osoby niewinnej bez wątpienia stanowią dostateczną gwarancję dotyczącą ustalenia sprawstwa podejrzanego w kontekście jego odpowiedzialności karnej. Filozofia stosowania ugody procesowej w sposób bezpośredni odnosi się do szybszego zakończenia postępowania karnego, a tym samym w sposób jednoznaczny realizuje kolejny cel tego postępowania, czyli rozstrzygnięcie sprawy w rozsądnym terminie. $Z$ kolei sądowa weryfikacja przy udziale pokrzywdzonego ustalonego wniosku pomiędzy prokuratorem a podejrzanym zapewnia trafne zastosowanie norm prawa karnego w celu kształtowania prewencji ogólnej i szczególnej. W tym kontekście zastosowanie rozwiązań przyjętych w art. $335 \S 1$ i 2 k.p.k. jest teoretycznie obwarowane gwarancjami procesowymi, które powinny pozwolić na realizację wszystkich celów postępowania karnego.

W doktrynie i orzecznictwie utrwalił się pogląd, iż sąd jest związany wnioskiem o konsensualne zakończenie postępowania, a jego ewentualna modyfikacja może nastąpić wyłącznie przy udziale stron postępowania, a więc prokuratora, oskarżonego i pokrzywdzonego, który powinien 
być należycie powiadomiony o terminie i miejscu posiedzenia. Dał temu wyraz Sąd Najwyższy w wyroku z dnia 7 września 2017 roku:

Przewidziana w art. 335 k.p.k. instytucja skazania bez przeprowadzania rozprawy jest jedną z form konsensualnego zakończenia procesu karnego. Konsensualne zakończenie postępowania karnego, od czasu nowelizacji ustawy procesowej z dniem 1 lipca 2015 r., polega nie tylko na uwzględnieniu dołączonego przez prokuratora do aktu oskarżenia wniosku o wydanie na posiedzeniu wyroku skazującego i orzeczenie uzgodnionych z oskarżonym kar lub innych środków, przewidzianych za zarzucany mu występek (art. $335 \S 2$ k.p.k.), ale również zgodnie z nowym uregulowaniem, mającym na celu dalsze uproszczenie postępowania przygotowawczego, na uwzględnieniu wniosku o wydanie na posiedzeniu wyroku skazującego, złożonego przez prokuratora zamiast aktu oskarżenia w sytuacji, gdy oskarżony przyznaje się do winy, w świetle jego wyjaśnień okoliczności popełnienia przestępstwa i wina nie budzą wątpliwości, co pozwala nadto prokuratorowi zaniechać prowadzenia dalszych czynności (art. 335 § 1 k.p.k.). Uwzględniając na podstawie art. $343 \S 6$ k.p.k. wniosek prokuratora o wydanie na posiedzeniu bez przeprowadzenia rozprawy i orzeczenie uzgodnionych z oskarżoną środków przewidzianych za dany występek (art. $335 \S 1$ k.p.k.), czy też wniosek prokuratora o wydanie na posiedzeniu wyroku skazującego, dołączony do aktu oskarżenia (art. 335 § 2 k.p.k.), sąd związany jest treścią takiego wniosku. Oznacza to, że potrzeba dokonania w tym zakresie jakichkolwiek zmian uzależniona jest od dokonania modyfikacji treści wniosku przez strony. Wydanie orzeczenia odbiegającego od uzgodnień poczynionych pomiędzy oskarżycielem publicznym a oskarżoną stanowi zaś rażące naruszenie przepisów prawa procesowego art. $343 \S 6$ i 7 k.p.k., mające istotny wpływ na treść orzeczenia ${ }^{15}$.

W przypadku gdy sąd nie uwzględnia wniosku złożonego w trybie art. $335 \S 1$ lub $\S 2$ k.p.k. i brakuje możliwości dokonania jego modyfikacji przy udziale stron postępowania, obowiązują dwie możliwości dalszego procedowania uzależnione od tego, czy mamy do czynienia z wnioskiem samoistnym, czy też dołączonym do aktu oskarżenia.

Jeżeli wniosek złożony na podstawie art. 335 § 1 k.p.k. nie zostanie przez sąd uwzględniony, następuje wówczas zwrot sprawy do fazy postępowania przygotowawczego w celu dalszego procedowania. Decyzja sądu wydana w tym zakresie jest niezaskarżalna i oznacza konieczność kontynuowania czynności w sprawie. Organ procesowy ma wówczas kilka sposobów załatwienia sprawy. Przede wszystkim nie jest związany swoim uprzednim stanowiskiem i może postępowanie przygotowawcze umorzyć na zasadach ogólnych, ponadto może po przeprowadzeniu po-

15 Wyrok Sądu najwyższego z dnia 7 września 2017 r., sygn. IV KK 271/17, LEX 2390755.

Nowa Kodyfikacja Prawa Karnego 50, 2018

(C) for this edition by CNS 
stępowania przygotowawczego wnieść akt oskarżenia, przy czym akt oskarżenia może zawierać wniosek o skazanie bez przeprowadzenia rozprawy, ale złożony w trybie art. 335 § 2 k.p.k. Zgodnie z brzmieniem art. $335 \S 4$ k.p.k. możliwe jest także ponowne skierowanie wniosku samoistnego, ale tylko w określonych przypadkach. Z treści przywołanego przepisu wynika, iż ponowne wystąpienie $\mathrm{z}$ takim wnioskiem jest możliwe, jeżeli zwrot nastąpił z przyczyn wskazanych w art. $343 \S 1,2$ lub 3 k.p.k. Przepis art. 343 k.p.k. w przywołanym zakresie uzależnia uwzględnienie wniosku przez sąd od dokonania w jego treści określonych zmian. W grę wchodzą trzy sytuacje, a więc kwestia naprawienia szkody przez oskarżonego lub zadośćuczynienia w przypadku gdy nie ma zastosowania art. 46 k.k., przy czym należy mieć na uwadze, że przepis ten odwołuje się do treści art. 341 § 3 k.p.k., który zakłada możliwość zarządzenia przerwy w posiedzeniu lub odroczenia jego terminu. Wydaje się, iż ze względów celowościowych wskazane jest zastosowanie najpierw tej instytucji, a dopiero następnie dokonanie zwrotu sprawy. Ponadto sąd może dokonać zwrotu sprawy, jeżeli pokrzywdzony należycie powiadomiony o terminie posiedzenia sprzeciwi się uwzględnieniu wniosku. Ewentualność ta była opisywana szczególnie w świetle wskazań metodologicznych. W tym miejscu wymaga podkreślenia, że wyrażona uprzednio przez pokrzywdzonego zgoda może na posiedzeniu zostać cofnięta i stanowisko wyrażone w tym zakresie przez pokrzywdzonego jest wiążące dla sądu, co wynika ze stanowiska orzecznictwa i doktryny ${ }^{16}$. Wreszcie trzecia sytuacja, która dotyczy możliwości zwrotu sprawy w przypadku złożenia wniosku w trybie art. $335 \S 1$ k.p.k., wiąże się z koniecznością zmiany treści wniosku przez prokuratora, co powinno być zaakceptowane przez oskarżonego oraz pokrzywdzonego. W orzecznictwie i doktrynie ugruntowaną pozycję znalazł pogląd, iż sąd nie może modyfikować wniosku złożonego w trybie art. 335 § 1 k.p.k. i nie może go samodzielnie modyfikować.

Instytucja dobrowolnego poddania się karze przez oskarżonego wpisała się na stałe do polskiej procedury karnej. Jej ewolucja wskazuje na to, iż zmierza ona do uproszenia w tym zakresie postępowania kar-

16 Wyrok Sądu Najwyższego z dnia 5 lutego 2013 r., sygn. III KK 252/12, KZS 2013/4, poz. 40; kodeks postępowania karnego. Komentarz... 
nego, a tym samym do jego przyspieszenia. Ostatnio przeprowadzona nowelizacja art. 335 k.p.k. pozwoliła na skierowanie wniosku o dobrowolne poddanie się karze w każdej sprawie o występek, a także wprowadziła instytucję wniosku samoistnego, który może zostać wysłany do sądu bez aktu oskarżenia. Obecny zakres jej stosowania w procedurze karnej wskazuje na to, że stanowi ona dla organów procesowych dobre narzędzie finalizowania określonych spraw karnych, w których doszło do niebudzących wątpliwości ustaleń w zakresie sprawstwa poszczególnych osób. Zobrazowaniem tego mogą być aktualne dane statystyczne dotyczące działalności powszechnych jednostek organizacyjnych prokuratury na szczeblu prokuratur regionalnych w pierwszym półroczu 2018 roku, z których wynika, iż 80,92\% spraw skierowanych z aktem oskarżenia zawierało dołączony wniosek, który został złożony w trybie art. 335 $\S 2$ k.p.k., natomiast sprawy przesłane do sądu z wnioskiem złożonym w trybie art. $335 \S 1$ k.p.k. stanowiły $15,42 \%$ spraw przesłanych z prokuratur do sądów ${ }^{17}$.

\section{Consensual conclusion of preliminary proceedings under Article 355 of the Code of Criminal Procedure}

Summary

The paper focuses on in-court settlement under Article 335 of the Code of Criminal Procedure and its procedural consequences. In particular, the author presents the findings of theory and practice resulting from an analysis of case law concerning the functioning of the consensual mode of proceedings in the Polish Criminal procedure.

Keywords: criminal proceedings, consensual modes, in-court settlement.

17 Informacja statystyczna Prokuratury Krajowej dot. wyników pracy powszechnych jednostek organizacyjnych prokuratury za pierwsze półrocze 2018 roku, znajdująca się w piśmie Prokuratury Krajowej z dnia 17 sierpnia 2018 r., sygn. PK XII BIA 037.42.2018. 